\title{
THE MAKING OF JOSE GARCIA VILLA'S FOOTNOTE TO YOUTH
}

\author{
Jonathan Chua \\ Ateneo de Manila University \\ jchua@ateneo.edu
}

\begin{abstract}
This article recounts the story behind the publication of Villa's stories and his book Footnote to Youth: Tales of the Philippines and Others (1933) in the United States. First, the conditions of the American literary marketplace are briefly described. Second, documents pertaining to the realization in print of Villa's stories and his book are analyzed as sites of negotiations between colonial subject (Villa) and the colonial master (his American editors and publishers). Finally, an account of how Villa was made to circulate in the Philippines after the publication of his stories and his book in the United States is given. From these discussions the article hopes to show that Villa's self-fashioning by publication was both subject to and critical of the colonial condition, alternately reinforcing it and challenging it.
\end{abstract}

\section{Keywords}

Philippine literature in English, book history, postcolonialism, exotic, author

\section{About the Author}

Jonathan Chua teaches at the Department of Interdisciplinary Studies of the Ateneo de Manila University. He is the editor of The Critical Villa: Essays in Literary Criticism by Jose Garcia Villa (2002). His edition of the collected short stories of Jose Garcia Villa is forthcoming from the Ateneo de Manila University Press. 
THE PUBLICATION OF JOSE GARCIA VILLA'S BOOK OF SHORT STORIES Footnote to Youth: Tales of the Philippines and Others by Charles Scribner's Sons in 1933 is regarded as a milestone in Philippine literary history. Here was the first collection of short stories by a Filipino to be published in the United States, just eight years since the publication of what is generally acknowledged as the first successful short story in English by a Filipino, Paz Marquez Benitez's "Dead Stars."

Although in the decades that followed, the book was overshadowed by Villa's poetry, there appears to be renewed interest in Villa's fiction. The stories in the book are the subject of three recent studies on Villa: Denise Cruz's "Jose Garcia Villa's Collection of 'Others': Irreconcilabilities of a Queer Transpacific Modernism," Philip Holden's “Unbecoming Rizal: Jose Garcia Villa's Biographical Translations," and Martin Joseph Ponce's "Jose Garcia Villa's Modernism and the Politics of Queer Diasporic Reading." Cruz's study argues that Villa's book is fraught with "irreconcilables-the uneasy, the troubling, and the disruptive within representational practices" (25). Such, for instance, are Villa's queer stories, because they put into question the myth of the immigrant finding sexual and artistic freedom in the United States (39-45). Ponce's study similarly makes the case for Villa's stories as critiques of sexual norms in a transnational context. Holden's analysis of four of Villa's stories shows how these disrupt official narratives about Jose Rizal and also challenge a brand of nationalism (295-300).

It is important to mention also Timothy Yu's "Asian/American Modernisms: Jose Garcia Villa's Transnational Poetics," a longer version of his "The Hand of a Chinese Master': Jose Garcia Villa and Modernist Orientalism," and a rejoinder by E. San Juan, Jr., "Jose Garcia Villa-Critique of a Subaltern Poetics." Although the main concern of these essays is the context for the American reception of Villa's poetry in the United States, Yu's "Asian/American Modernisms" makes a detour to Footnote to Youth on its way to analyze Villa's attempt "to gain access to the modernist canon" (348) and his subsequent ejection from that canon by the Orientalism that inheres in modernism.

What has yet to be told, then, is the story behind the publication of Villa's individual stories in the United States and of the collection Footnote to Youth. The story bears telling for what it may reveal about the material conditions of literary publication for somebody like Villa, a colonial subject located in the metropolitan center, a subject, moreover, with strong views about himself as a writer; the impact of publication on the formation of literary reputation; and the uses to which such a reputation may be put in the colonial context.

What follows is a presentation of the process of the publication of Villa's stories and his book in the United States. First, the conditions of the American literary marketplace are briefly described. Second, correspondence, paratextual matter, and documents pertaining directly to the realization in print of Villa's stories and 
his book are analyzed as sites of negotiations between colonial subject (Villa) and the colonial master (his American editors and publishers). Finally, an account of how Villa was made to circulate in the Philippines after the publication of his stories and book in the United States is given. From these discussions the paper hopes to show that Villa's self-fashioning by publication was both subject to and critical of the colonial condition, alternately reinforcing it and challenging it. The article is thus not an analysis of 'literary works' (like stories) per se but an analysis, to use Jonathan Bates's formulation, of the situations within which "literary acts" take place (vii).

\section{Putting Villa in Circulation}

Between 1931, the year that a story by Villa first appeared in an American publication, and 1933, the year that his collection of short stories was published, Villa's stories came out in the pages of American periodicals eighteen times. The table below shows the chronology:

\begin{tabular}{|c|c|c|}
\hline STORY TITLE & $\begin{array}{l}\text { PUBLICATION } \\
\text { OUTLET }\end{array}$ & $\begin{array}{l}\text { DATE OF } \\
\text { PUBLICATION }\end{array}$ \\
\hline $\begin{array}{l}\text { "Malakas: A Story of } \\
\text { Old-Time Philippines" }\end{array}$ & New Mexico Quarterly & May 1931 \\
\hline "Untitled Story" & Clay & Autumn 1931 \\
\hline “Given Woman" & Scribner's Magazine & 23 December 1931 \\
\hline "Footnote to Youth" & The Frontier & January 1932 \\
\hline "White Interlude" & Clay & Winter 1931-1932 \\
\hline "Walk at Midnight" & Clay & Winter 1931-1932 \\
\hline "Resurrection" & Clay & Winter 1931-1932 \\
\hline “Like My Boy" & Clay & Spring 1932 \\
\hline "Valse Triste" & Clay & Spring 1932 \\
\hline “Little Tales” & Clay & Spring 1932 \\
\hline
\end{tabular}




\begin{tabular}{|c|c|c|}
\hline STORY TITLE & $\begin{array}{l}\text { PUBLICATION } \\
\text { OUTLET }\end{array}$ & $\begin{array}{l}\text { DATE OF } \\
\text { PUBLICATION }\end{array}$ \\
\hline "Daughter of Rizal" & Clay & Spring 1932 \\
\hline "Death of a Boy" & Clay & Spring 1932 \\
\hline $\begin{array}{l}\text { "The Man Who } \\
\text { Looked like Rizal" }\end{array}$ & The Frontier & May 1932 \\
\hline $\begin{array}{l}\text { "Kamya: A Story of } \\
\text { Old-Time Philippines" }\end{array}$ & New Mexico Quarterly & May 1932 \\
\hline “The Fence" & Prairie Schooner & Summer 1932 \\
\hline "Death of a Boy" & The Lion and Crown & Fall 1932 \\
\hline "The Son of Rizal" & Prairie Schooner & Winter 1932 \\
\hline "Story for My Country" & Prairie Schooner & Spring 1933 \\
\hline
\end{tabular}

What might account for this record? Why, for instance, was Villa published in those magazines and not others? The publication of Villa's stories in the United States, this section suggests, appeared to be conditioned by three interrelated things: (1) the general economic slowdown, (2) the trends in the American writing scene, and (3) Villa's status as a colonial subject.

Villa's entry into the United States, in 1930 to study at the University of New Mexico, coincided with the worsening of the Great Depression. A series of bank runs that had begun that year led to the closure of 10,0oo banks. Unemployment rose from 3.2 percent in 1929, the year the stock market crashed, to about 24.9 percent in 1933 (McElvaine 75).

The situation did not spare the book industry. Book production decreased significantly. In 1929, there were 214,334,000 new books printed; in 1933, the year that Villa's book was published, only 110,790,00o, "many millions of which ... languish[ed] unbound in warehouse" (Hart 248). Many book-buyers became book-borrowers: the sale of fiction "dropped 9 per cent below the general market," but the number of library membership ballooned by 4,00o,ooo more in those years (ibid.). Unsold books became returnable, so that publishers became more selective, preferring to invest in sure sellers and established names (Korda 56-57). Although Villa was already a literary celebrity in the Philippines-the author of over thirty short stories and a critic to boot-he was an unknown in the United States. For him 
to break into print there would mean his competing not with student writers who were just learning the English language, as it had been the case in the Philippines, but with the likes of Ernest Hemingway, William Faulkner, and F. Scott Fitzgerald.

The time also saw the increased disparity in the American literary scene between, broadly speaking, highbrow literature, on the one hand, and middle- and lowbrow entertainments, on the other, a divide which had started after World War I (Burt 336). An indicator of this state of things was the spectrum of magazines, in which new fiction could be published, that emerged during that time. At one end stood the so-called little magazines-small-press affairs, decidedly literary or artistic in content, non-commercial in intent, exclusive in readership, and usually short-lived. According to Hoffman, Allen, and Ulrich in their pioneering study of the type, the little magazines addressed two needs felt by writers who styled themselves as being in the advance guard: "rebellion against traditional modes of expression and the wish to experiment with novel (and sometimes unintelligible) forms; and a desire to overcome the commercial or material difficulties which are caused by the introduction of any writing whose commercial merits have not been proved". ${ }^{2}$ At the other extreme was the pulp magazine, whose number and circulation peaked at the same time that little magazines were being founded one after another. Thus, The Dial (est. 1920), transition (est. 1927), and Story (est. 1931), shrines to experimental or high modernist writings, all co-existed with magazines like Black Mask (est. 1922), whose cover announced that it was an "Illustrated Magazine of Detective, Mystery, Adventure, Romance, and Spiritualism," and Amazing Stories (est. 1926), which was devoted to science-fiction. ${ }^{3}$

Somewhere in the middle were magazines such as Harper's, Atlantic Monthly, and Scribner's. These were sometimes referred to as "quality magazines," because "they addressed an audience well above average in income and intellectual curiosity" (Petersen 2). Occupying a lower tier but still above the pulps were magazines like the Saturday Evening Post, "symbolic of the reading fare of middle-class America" (12). All these magazines carried fiction that was not quite pulp, genre, or formula, but that, because the magazines were driven by advertising revenues and were intended for mainstream readership, was nonetheless conventional by little magazine standards. Occasionally there was room for the high quality short stories in their pages-Hemingway, Caldwell, and Faulkner were published there-but it was not their business to herald new movements or new voices. ${ }^{4}$

In this milieu, how was Villa going to position himself?

While still in the Philippines, Villa had already been styling himself as an artist cut above the rest, although he had started out, in 1925, as a writer of popular fiction not much different from that written by his contemporaries. In an interview in 1929, he had declared, "When I write my masterpiece . . . it shall be a story nobody will appreciate but myself, nobody can accept but myself, for I shall write of the naked facts of life to which all men will close their eyes and stuff their ears in horror" (qtd. in Sabado 50). Beginning in 1927, he began what would be an 
annual activity of writing assessments of the Philippine short story scene. In his first annual review, he deplored how backward the Philippine short story was: "95 percent or more of these [stories] are pure, unadulterated literary trash" (Critical Villa 36). It was lamentable, he continued, that "most readers [did] not know how to appreciate stories other than the love story" (37). By the time he left the country to go to the United States, he was already called the "messiah of short story writing in the Philippine Islands" (Brunschwig 5).

Sherwood Anderson, whose stories shattered romantic interpretations of American life and who was himself associated with the advance guard in American fiction, became his model. ${ }^{5}$ So devoted was Villa to Anderson that he even wrote Anderson what must be called a fan letter: "I esteem you so highly, sir, that I think there never will be another writer so great as you. ... It is my ambition to be able to write like you, Mr. Anderson. I want to be like you because you are the greatest of them all" (7 Feb. 1930).

The editor-critic Edward J. O'Brien was another influence. Not surprisingly, O'Brien was one of Anderson's earliest champions (Wright 15-16). Each year O'Brien edited an anthology of what he thought were the best short stories-a good number of them invariably coming from the little magazines-and awarded a story one, two, or three asterisks depending on how it passed his tests of substance and form. It was O'Brien's anthologies, Villa remarked in an interview (Alegre and Fernandez 298), that became his informal guide to writing. His own annual selection of the best Filipino short stories, using the same tests of substance and form, bore the stamp of O'Brien.

In the United States, Villa kept to his vision of himself as a writer in the style of Sherwood Anderson and a critic in league with Edward J. O'Brien. If anything, his position hardened. ${ }^{6}$ One expression of this development was that he founded a little magazine, which he called Clay: A Literary Notebook. The magazine unequivocally made his position known: on the first page of the second issue, one reads, "In Clay: A Literary Notebook you will find only distinguished fiction by vital modern writers"; the cover of the third issue declares that the magazine prints "only honest writing, works of sincerity and truth" and has no room for the "machine-made, formula story." In letters of introduction Villa also underscored the artistic intentions of the magazine. In a letter to William Carlos Williams, for instance, he describes that Clay is non-commercial and that it takes after the Gyroscope, a magazine that Williams was editing (5 Aug. 1931).

The choice to be this type of writer, however, inevitably limited Villa's readership. As the table shows, it was the little magazines that were hospitable to Villa. Even within the little magazine circuit, however, the welcome was apparently not without reservations. Based on existing correspondence between Villa and Richard Johns, we know that Villa tried repeatedly to be published in Pagany, another little magazine. ${ }^{7}$ In at least three instances, he received notice that his stories had been accepted for publication, but the magazines in question (This Quarter, Contempo, 
and Contact) either folded up before they could print his stories or eventually rejected them. ${ }^{8}$ In the end, Villa was kindest to Villa: he published his own stories nine out of eighteen times within the space of a year.

It was not, however, that Villa altogether avoided the mainstream American magazine. A. E. Litiatco, literary editor of the Graphic, suggests in an article that Villa might have submitted stories to Redbook and Collier's but that these, being commercial magazines, turned him down (Litiatco, "The Why of Rejection Slips" 45). We know from the table that Villa tried to get himself published-and succeeded in doing so-in Scribner's at least.

What is less known is that he was also repeatedly rejected by Scribner's. The letters exchanged between him and Kyle S. Crichton, assistant editor of the magazine, are instructive for what they reveal about publishing somebody like Villa in the United States. They suggest that it was not only economic realities or differences in literary inclination that conditioned his publishability in the American mainstream; it was also his ethnicity. ${ }^{9}$

\section{Getting into Scribner's}

Litiatco recounts that the first short story Villa ever sent for publication in Manila came out "within a fortnight of its submission" ("Jose Garcia Villa Goes Up Another Step" 6). In the United States, however, the going was to prove tough. In his first bid to get himself published there, Villa sent to Scribner's "Footnote to Youth," considered by his peers as one of his best short stories-and Scribner's declined (Crichton, Letter to Villa, 19 Mar. 1931). ${ }^{10}$

His next attempt was with "The Man Who Looked like Rizal." This time Villa used O'Brien, whom he had befriended, as an endorser. In a cover letter to Crichton, Villa quoted O'Brien's positive remarks on his stories (7 Mar. 1931). O'Brien's imprimatur, however, failed to get Villa's story published in Scribner's.

Villa would be rejected at least twice more before "Given Woman" would see print in the magazine, in its December 1931 issue. After getting that break, however, he would be rejected at least four times, and never again would any of his stories be printed in Scribner's.

Crichton pleaded lack of space (19 Mar. 1931; 14 Apr. 1931); sometimes he merely stated, "We don't like it quite enough" (24 Oct. 1931; 6 Jun. 1932). Still, Crichton regularly cushioned his rejection letters with encouragement. Sometimes, he would even praise a story, quickly adding, however, that it was not for Scribner's. It is in those rejection letters that, setting aside purely subjective evaluations of the merits of a story, one sees the economics of publication at work.

Early on, Villa made his orientation as a writer clear to Crichton. He introduced himself this way: "I write stories because I love the work. I am not interested in formula stories, I must admit" (23 Mar. 1931). With that self-description, Villa had effectively put himself in the corner against trade. Meanwhile, Crichton's letters 
adverted to the conflict between, on the one hand, the demands of commerce, made more urgent by the Great Depression, and the elitism of high art, on the other. One of Crichton's letters reminded Villa, "After all we are a hard-boiled capitalistic magazine with readers of a like type"; as such, it is prevented from publishing certain materials regardless of how the editors may want to (6 Jun. 1932). In another instance, Crichton remarked of Villa's story "Yet Do They Strife" that it was "too poetic," and while he thought the story "very beautiful," it might not be for a "magazine in general circulation" like Scribner's (4 Nov. 1932). ${ }^{11}$

Thus, while Crichton encouraged Villa to keep writing, he also had to suppress his enthusiasm in favor of the magazine's business interests. As he explained in an "insider" essay, which appeared, appropriately enough, in Villa's own Clay, he was appreciative of the "better class story"; however, "editing a national magazine is a business proposition" ("Advice to a Young Man about to Lose His Shirt" ii). There is a limit to what such magazines can accept, and some stories are "still too advanced even for those most cordially attracted to the experimental and novel" (ibid.).

The other issue that Crichton's letters reveal involves what Villa as a foreigner could write about, that is, the question of how to position the colonial subject who was not just at the gate but who had got, as it were, a toe in. Crichton's comments on Villa's "Untitled Story" are telling. The story is both experimental-being made up of short passages, sometimes lyrical, sometimes prosaic, often introspective, each one numbered like a diary entry-and un-Philippine, the story being set in the United States, although the narrator is ostensibly from the Philippines. A narrative is discernible but it is secondary to the narrator's private ruminations that find expression in surreal imagery:

39

I was very angry I became a poet. In fancy my anger became a gorgeous purple flower. I made love to it with my long fingers. Then when I had won it and it shone like a resplendent gem in my hand I offered it to my father. (Villa, Footnote 8o-81)

Crichton wrote: "We all thought that the second story about your American experiences [i.e., "Untitled Story"] was a distinct let-down from the Rizal story. It had the bad quality of being 'written' and seemed much more self-conscious and affected than the one with the Philippine setting" (14 Apr. 1931). He suggested that Villa "cling to that Philippine material of [his] own until [he had] definitely conquered all of [his] artistic problems" (ibid.). In this regard, Crichton was not unique: Sherwood Anderson, too, had advised Villa, "Do not try to be an American" (Anderson, Letter 2 to Villa, n. d.). ${ }^{12}$

The preference for "Philippine material" from a Filipino writer seems connected to the question of regular form. Crichton's letter of 3 August 1931 about a story, whose title is unfortunately not mentioned, is telling. Crichton remarked that the 
story was ineffective because it was "a bit too much of a sketch," adding that America was possibly turning out to be a negative influence on his work. He advised Villa to channel his emotions into the "regular story form rather than waste it on these sketches. In other words, don't let America get your goat."

Here Crichton appeared to conflate "America" and experimentalism and, by implication, given his earlier remarks on "Untitled Story," to identify the "regular story form" with Philippine matter. Villa's attractiveness and publishability, the letters suggest, lay in his foreignness. His attempt at writing about experiences in America, and that in an unconventional manner, like "Untitled Story," was criticized as being affected and "written." It was as though such writing was unnatural, not native to a "native," and thus was inauthentic. Further, by writing in that manner Villa was threatening, against Anderson's admonishment, to be an "American," and as such, he potentially was unsettling the binary between colonial subject and master, the periphery and the center. It would be more comfortable for the colonizing power to keep him "in his place" by delimiting him to "authentic" writing. ${ }^{13}$ Villa seemed to anticipate what Graham Huggan describes in The PostColonial Exotic: Marketing the Margins: many contemporary postcolonial writers are made to trade on their exoticism for them to circulate in the metropolitan centers, even as they try to criticize such a system. The situation reinforces the essentialisms that maintain the asymmetries between the West and their former colonies. ${ }^{14}$ In the end it was Story, a magazine based in Vienna, and Clay that published "Untitled Story."15 Outside of the Philippines, its two sequels ("White Interlude" and "Walk at Midnight"), written in the same experimental vein and moreover, containing counternormative sexuality, would appear only in Clay. ${ }^{16}$

Even when Villa got his stories into the little magazines, which in theory were ideologically more progressive, the process was not always untainted by Orientalism. Lowry C. Wimberly, editor of the Prairie Schooner, the little magazine most hospitable to Villa next to Clay, commended his story "The Son of Rizal" and accepted it for publication. Wimberly remarked that the magazine "usually insists on strictly American setting," but it "just could not let this story escape the Schooner" despite the story having an "exotic setting" (qtd. in ". . . the latest about J.G.V." 40). In this story, an unnamed narrator, a first-class passenger aboard a train to Tayabas, observes a "small, bark-colored man lugging a long narrow buri bag which in the native tongue is called bayong" (Villa, "The Son of Rizal" 1), who is trying to get aboard the train. ${ }^{17}$ The narrator invites the man to his compartment, and there the man declares that he is the son of Rizal. The narrator finds out later that the man is really Juan Kola, whose father had so maltreated him that he decided to assume a false identity as Juan Rizal, the son of Rizal. The narrator refrains from disabusing the man, allowing him the illusion that has made his life bearable. ${ }^{18}$

In hindsight, it is perhaps telling that Villa's first story to be published in the United States should be "Malakas," a story about the eponymously named hero's quest for love over three generations, set in precolonial Philippines, and written 
in rather purplish prose: "Full twenty handsome years was he [Malakas] when the river Pasig yet was young, when cool, green clumps of bamboos arbored its soft sandy banks" (Villa, "Malakas" 167). As published in the New Mexico Quarterly, it was given the subtitle, "A Story of Old-Time Philippines." In the Philippines, where it had been previously published, it was simply "Malakas."

Admittedly, one might argue that the best of Villa's stories were indeed those that were set in the Philippines, so that what could be construed as Orientalism was merely a coincidence. The fact remains, however, that Villa's manuscripts were not dissociated from his foreignness when they were being evaluated. Moreover, though perhaps the point is debatable, he was also being restricted to what was 'Philippines' (that is, as rural and poor, as in "The Son of Rizal," or else as primitive and exotic, as in "Malakas: A Story of Old-Time Philippines"). Whether Crichton was representative of American editors awaits more evidence, but that even Wimberly should manifest a like mindset suggests that he was. ${ }^{19}$

These developments would seem to anticipate what Yu suggests about the American reception to Villa's modernist poetry later, that it "threatens to overturn the orientalist hierarchy at the heart of modernism, in which classic Asian art and literature provides passive inspiration to a vibrant Western modernism" (“The Hand of a Chinese Master"' 47; "Asian/American Modernisms" 351), and hence must be contained. This "ghettoizing" would continue to hound Villa as he sought to see his stories printed as a collection, and his notion of himself as serious writer (and thus from the point of view of book trade, a writer whose market is limited) would complicate matters. ${ }^{20}$

\section{Getting an Imprint}

From a letter that Villa wrote to Crichton we know that Villa, buoyed by O'Brien's praises, began preparing a book-length manuscript of his short stories for publication early in 1931 (23 Mar. 1931). In his letters, O’Brien offered to broker for Villa in Britain. Among the publishers that he thought could be interested in the manuscript were Alfred Knopf, Jonathan Cape, and Edward Garnett (10 Jan. 1931; 5 Apr. 1931). Meanwhile, Villa also sent his manuscript to the book department of Charles Scribner's Sons.

As the year came to a close, however, none of the houses accepted Villa's manuscript. O'Brien attributed Cape's silence to the recent death of his wife (18 Jul. 1931). There was no mention of the other publishers in the subsequent letters at hand between O'Brien and Villa. From a letter to Crichton from Harvey Fergusson, who describes Villa as "look[ing] like a Chinaman," we learn that Knopf had turned down the manuscript "on account of hard times," though not without giving it "high praise," and that Fergusson had suggested to Villa to send his manuscript to Scribner's (9 Sept. 1931). Crichton replied to Fergusson that Maxwell Perkins, the editor of the house, had already turned it down because short stories were 
difficult to sell: "You know how impossible it is to sell short stories even in the well established office" (14. Sept. 1931).

The hunt for a publisher was resumed in early 1932, after Villa had graduated from the University of New Mexico. Villa's father was sending him to Columbia University for him to take up a master's (Fergusson), but Villa, never really interested in academics, had other plans. ${ }^{21}$ He shuttled between New York and New Mexico while trying to sell his manuscript of short stories. By this time, too, O'Brien had made his approbation of Villa's work public. He had identified Villa as one of the most promising young writers in the United States in an interview published in the Chicago Daily Tribune, and he had written an introduction to Villa's manuscript ("Villa and the Short Story" 6).

Nonetheless, publishers turned him down. Macmillan wrote him, "It is sadly true that in this work-a-day world we have to consider not only the merits of our books, but also the possibilities for sale. We donot [sic] see those possibilities here. ... Frankly, we are certain to lose greatly in money by publishing this collection" (de la Torre Bueno, Letter to Jose Garcia Villa) - this despite Villa's offering to pay part of the publication cost and to waive his royalty (de la Torre Bueno, Letter to Granville Hicks). When Villa resent the manuscript to Scribner's, he got a similar answer. "Poor general business conditions," Crichton wrote him, made it risky for the house to publish the story collection (22 Mar. 1932). Crichton suggested that he try again after six months (8 Apr. 1932).

The situation reached a crisis around July 1932. Villa's father had got wind of the fact that his son had not been attending school. He ordered Villa to return to the Philippines, cutting him off, "allowance and everything" (Villa, Letter to Crichton, 11 Jul. 1932). Villa believed, however, that the publication of his manuscript would change his father's view of him, and asking Crichton to intercede for him, he offered the manuscript again to Scribner's (ibid.).

This time it was Perkins himself who advised Villa to return to the Philippines; after all, Villa's best stories, Perkins opined, were about life in the Philippines. Villa's creativity would not be hampered by his returning to the Philippines, which might even be good for him (31 Jul. 1932). Perkins's letter hinted that Villa's manuscript might yet be published unless business did not improve; in the meantime, however, he was rejecting the manuscript (ibid.).

Notwithstanding his father's order and Perkins's advice, Villa decided to stay on in the United States. Meanwhile, his output as a short story writer had dwindled considerably. Although, as the table shows, he would publish three more stories in the United States after the summer of 1932, these were not entirely new stories. "The Son of Rizal" had been published in the Philippines in 1929; a version of "Death of a Boy" had been completed in 1931; and he had been selling "Story for My Country," published in 1933, as early as July $1932 .{ }^{22}$ Ironically, when O’Brien's Best Short Stories came off the press, it was dedicated to him. Villa had the most number of stories in that year's Roll of Honor. 
Villa renewed negotiations with Scribner's in May 1933. He asked Crichton to re-open the case with Perkins, with this proposition: "I have saved enough now to defray the whole expense-but I only want to have the book come out under the imprint of a house" (17 May 1933, emphasis Villa's). Even the backdoor to the house, however, remained shut. He was told to wait for "next Spring" assuming that "business shows signs of picking up" (Crichton to Villa, 18 May 1933). At that, Villa reiterated his offer: "You're putting out Hemingway-of course he has the name \& you won't lose money-but you won't lose in my case either-on my proposition. All I need is an imprint" (Villa to Crichton, 23 May 1933). ${ }^{23}$

Villa's letter to Perkins was even more impassioned: "It's a hard job-waiting, Mr. Perkins. ... The book preys on my mind (I speak frankly) and prevents me from doing further work. That's why I want to get the load off and see it published. ... I will defray the whole production cost, to ensure you against losing any money; and I leave it to you to make the other arrangements for the handling of the book; it does not matter to me how much a share you want. I am not interested in the money side of it. In this way you don't stand to lose anything, and it will be a great help to me" (26 May 1933).

In June 1933 Perkins finally agreed to have the book published at Villa's expense. The house had never accepted such an arrangement before, Perkins explained, because it would suggest that Scribner's had no confidence in their own books. "But we do think your book very exceptional, and times very exceptional" (1 Jun. 1933).

The specifics of the agreement were spelled out in his next letter to Villa (5 Jun. 1933): the cost of the printing would be $\$ 711.04$. The book would be sold at $\$ 2.50$ a copy, with Villa getting $\$ 0.375$ per copy sold. At least 2,ooo copies would be printed, which if all sold would be enough for Villa to recover his investment. ${ }^{24}$

Villa must have acceded, for in September 1933, Footnote to Youth: Tales of the Philippines and Others came off the press-a 323-page, 8-by-5 $\frac{1}{2}$-inch hardback of 19 stories with an introduction by O'Brien.

\section{Fashioning a Self}

The journey from manuscript to book seemed driven primarily by economics; marketing the book after it had been produced was more vexed. From the point of view of trade, the book was a commodity that needed to be sold. As the next section will show, playing up Villa's colonial origin was one way to sell it, but this strategy ran counter to Villa's self-imagining. When Villa wrote Anderson that he would take the advice and "not try to be an American" (Villa, Letter to Anderson, 7 Sept. 1930), he could not have realized the implications that his reply would have three years later.

In the late 1910 s and throughout the 1920s, the American reading public, reacting to the devastating aftermath of World War I, developed a taste for 
escapist romantic adventures ("exotic lands and the days of derring-do" [Hart 243]). Somerset Maugham and other writers who took their readers vicariously to Africa, Arabia, and the South Pacific became bestsellers (243-44). Villa was in a unique position in that he was not just an observer of exotic goings-on but was a "native" of the Philippines, affording readers an "emic" perspective, as it were.

In his book, Huggan presented cases of oppositional postcolonialism being recuperated by commodifying postcoloniality, situations where "'resistance' itself emerges as a commodified vehicle of symbolic power" (29). It would appear that some seventy years before the phenomenon of "Indo-chic," which Huggan analyzes as a recuperative discourse, Villa experienced a similar predicament. Unlike the writers that Huggan analyzes, however, Villa did not have a conscious political agenda; but like the fiction of those writers, Villa's book apparently was prepared with the metropolitan (specifically, American) audience in mind.

First, bibliographic details such as the subtitle, "Tales of the Philippines and Others," appear to emphasize Villa's otherness, just as "A Story of Old-Time Philippines" might have done. The number of italicized non-English words in the book, at least twenty, such as hilot, sawali, kinke, and even Biblia (where Bible was readily available) was another marker of Villa's otherness. In most cases, these words were left unglossed, although context clues and the reader's familiarity with Spanish would suggest their meanings. ${ }^{25}$ The cover, the spine, and the dust jacket all bore images of palm trees; arrowheads were used to create borders.

Second, O'Brien's introduction and the dust jacket also called attention to Villa's foreignness. O'Brien (4-5) wrote: “Mr. Villa's tradition is an ancient one. It goes back to and is deeply rooted in the country life of the Philippine Islands. . . Exiled from the lush tropical background of the Philippines, he sought in his new surroundings to impose the ascetic pattern of the American desert upon his memories and, in so doing, upon his writing as well" (italics added). He continued that Villa had come from "a totally unrelated civilization" (5). The blurb on the flap, probably written by O'Brien or adapted from his introduction, added, "His stories of Philippine life are written with great delicacy and beauty ... filled with a strange and magical quality that could come only from the Orient." These remarks highlighted the "exotic" setting of the stories while also erasing the reality of colonial relations that existed between the United States and the Philippines. Even though the Philippines had been an American colony for three decades, it was a "totally unrelated civilization" (Espiritu 77).

Third, what appears to be a draft of an advertising copy also traded on the Philippine setting of most of the stories. ${ }^{26}$ Villa's stories, it read, "have a magic in them and a strange quality of magic that must come from the Philippines." They had the advantage, it went on, like Kipling's stories, "of being about a strange land." Of Villa himself, the copy declared that he was "very shy" but was "of remarkable intelligence and sensitiveness," a description that reminds one of Fergusson's remark 
that Villa looked like a Chinaman - a version of the stereotype of the inscrutable Oriental'.

How did Villa himself stand in regard to this fashioning of him?

Villa's letter (23 Mar. 1931) to Crichton quoted earlier declared his orientation as a writer of non-commercial fiction. Another dimension of Villa's self-imagining was his universality. His pronouncements about what art is would imply an erasure of ethnicity or at least an undervaluing of its significance. According to an article by Carlos Quirino in 1932, Villa told him, "Good literature must appeal to all people-not to Filipinos alone." In Villa's article on the Filipino short story for 1932, his first extensive discussion of what good literature is, he explains that "it is only when writing is honest that it can assume the dignity of art-and short-story writing is justified only when it is an art. . . Does honest writing mean being factual, reportorial? No. It does not have to be history or sociology, which is factual" (Critical Villa 70). When Litiatco (“Jose Garcia Villa's First Book" 20) observed how sociologically inaccurate the protagonist of "Given Woman" was, Villa responded, "In all my stories, in all my work, I do NOT write about the Filipino, I write about $M A N$. I am not interested in the Filipino as a separate brand of humanity-I am interested in him as a human being, as a man" (Critical Villa 110).

Probably feeding into this notion were two personal traumas. The story is wellknown that before he went to the United States he had been fined by the Court of First Instance and had been suspended from the University of the Philippines for writing "obscene" poems. To be re-admitted he had to promise not to write such poems again, a condition he rejected. ${ }^{27}$ Villa was also rebelling against his father, Simeon Villa, with whom he had never gotten along. According to E. San Juan, Jr., Villa was rebelling against what he thought was the "vulgar acquisitiveness and philistinism" (Toward 74-75) of his father. ${ }^{28}$ Simeon had also forced him to take up medicine and had objected to a literary career for him (Quijano de Manila 188). By the end of 1931, however, he had apparently conceded to Villa and issued a statement in the Graphic: "While he [Villa] is about it, he might as well make a complete job of it. Consequently, since he has completed his A. B. at the University of New Mexico, I am sending him to Columbia, which I understand gives good courses in literature" (qtd. in Note to Villa, "Given Woman" 22). When he discovered Villa's truancy, he wrote harshly to his son: "Si vuelves aqui, volverás siempre Xiro (o). Has salido xiro y volverás xiro" (5 Sept. 1932).

Apparently, Villa felt rejected by both fatherland and father. His interpretation of these events and the public persona he appeared to want to cultivate are inscribed in his bio-note in O'Brien's Best Short Stories of 1932. The bio-note, apparently based on an interview with Villa, reads in part, "Born in Manila, Philippine Islands. His father is a physician, and wanted him to follow a medical career. He finished his pre-medical course but could go no further. . . . Was expelled from the University of the Philippines in 1929 because it was claimed, he says, that his writing was immoral. ... He is very unacademic because he believes academism cramps the 
soul. As for the Philippines, he cannot stand the old-maidishness of its outlook on things" (293). Thus did Villa want to present himself.

The note was factually inaccurate: Villa did not finish his pre-medical course and he was not expelled but suspended. As a mechanism for self-presentation, however, the note with its exaggerations gave him a romantic gloss: he was a victim of the establishment (the university), a rebel against convention (opting to be a writer instead of pursuing a lucrative career in medicine or at least a stable and respectable one in the academe), and a vanguard (his contempt of "old-maidishness"). This romantic presentation of himself was an escape from the drab facts of history. While the note identified himself as being born in the Philippines, it was also suggesting that his destiny, including his readership, lies elsewhere-an idea that squared with his universalist aesthetics described earlier.

Villa, then, must have chafed at being pressured to write about things Philippines because he was from the Philippines. How, then, might he have reconciled being marked as a "native of the Philippine Islands" with his desire to write about 'man'? How did he resist getting commodified as a "native" for metropolitan consumption even as he wanted to get himself published in the center?

Villa attempted to erase his history, to resist the pressure to be other. Among the book's preliminaries is Villa's acknowledgment that "most of the stories in this volume have appeared in Clay, The Prairie Schooner, Scribner's Magazine, Story, The Frontier, The Lion and Crown, and The New Mexico Quarterly" (viii). What Villa did not say was that all except one of the stories were also published in magazines in the Philippines and that only "Given Woman" was first published in the United States. In short, Villa occluded the fact that he was first a Filipino writer, writing for a Filipino audience, before he became published in the United States for an American and presumably international audience.

From what we can gather about the production of the book, there are other traces of Villa's distancing himself from the Philippines. We do not know the exact configuration of his manuscript, but Villa as financier apparently had a free hand in selecting which stories were to be included. We know from a letter to Perkins that he had "Mirla" pulled out after the manuscript had been sent to press. He explained that he was unhappy with it because it was an early story (14 Jun. 1933). He also excluded "Mir-i-nisa" ("Villa Protests" 159). Both stories were of the same type as "Malakas" and "Kamya"-stories set in supposedly in precolonial times which would mark him out as other. They were also the stories that had established his reputation among readers in the Philippines and with which Filipino readers of that time would have identified him. ${ }^{29}$

To strengthen his claim to be the kind of writer that he was presenting himself to be, Villa also left out a big chunk of his corpus when he selected the stories that were to be included in the book. Until he went to the United States, he had already written some thirty stories. Half of these were stories that depict modern middleclass life in Manila, life as transformed by American colonial engineering. The plot 
situations and character types were arguably such as what one found in magazines like the Saturday Evening Post. These were urbane social comedies about lovesick co-eds or couples at each other's throat a la Jiggs and Maggie. In his view, these stories were commercial.

The battle lines, in sum, were drawn thus: the house was trying to capitalize on the exotic appeal of Villa's stories. The paratextual matter of the finished product and the official advertising matter played up the foreignness of Villa and his stories. While Villa must have been complicit in this self-fashioning-for the book was published with his funding - he also appeared to resist it, to downplay, if he could not deny, his origins. He included only two stories of high romance that would have called attention to his otherness ("Malakas" and "Kamya"). Meanwhile, to shore up his claims to being a serious writer he banished his social comedies and kept only the stories that would recall Anderson's in theme or those that were experimental in style.

The last strategy would seem to have produced an ironic effect. The exclusion of those stories of middle-class life in Manila, explicable by Villa's shift from one type of writing (what he thought was commercial) to another (what he thought was serious), inadvertently fed colonial discourse. Those stories not only could have challenged the claim that the Philippines was, in O'Brien's words, a "completely unrelated civilization" but also would have called attention to the fact of American colonialism. The characters, after all, were reading and writing in English, spouting American slang, and sporting the latest in American fashion. Villa was avoiding the label "native," but by omitting these stories of Americanized well-to-do Filipinos he perhaps fell into another kind of exoticism, the exoticism of poverty. All of the stories with a Philippine setting that one finds in the book represented the colony as poor and provincial. How the book, thus constituted, might have interpellated its American readers can be surmised when one recalls the position that the narrator of "The Son of Rizal" assumes-a mixture of fascination, condescension, and perhaps pity: "From my compartment in the train I could see that the thirdclass cars were filling with returning provincials who had come to the city-Manila .... They formed a motley, obstreperous group and crowded both the station platform and the steps to the cars. They bustled and palavered loudly like little children" (Villa, "Son of Rizal" 1).

Viewed under this light, Villa's bio-note quoted earlier was also ambivalent. By emphasizing how much of an outcast he was in the Philippines, he was also implying and affirming, inadvertently perhaps, the myth of American liberalism. In a letter to the literary editor of the Philippines Free Press, Villa wrote, "I don't want to come back home now because I have greater chances here in America" ("Short Story from Villa" 12). The United States was where rebels like him could be appreciated, if only by a select minority. ${ }^{30}$

When Footnote to Youth reached the critics, the reviews of the book in the American press would seem to affirm, inevitably perhaps, Scribner's packaging of 
Villa despite Villa. In her account of the reception to Villa's book, Lucila Hosillos observes, though without using the terminology, that they show evidence of Orientalist fascination. ${ }^{31}$ Quoting from a review by Horace Gregory in the Herald Tribune, Hosillos writes, "To an American reader, Villa's stories offered variety because they 'are news from an unknown country, the Philippines." Almost all the reviews identified Villa as a native of the Philippines. Many of these remark that his best stories are those with a Philippine setting. ${ }^{32}$

Yet the fascination also came with disavowal. As O'Brien asserted in his introduction, Villa, as an outsider, promised to offer American readers a fresh perspective on America. The reviewers, however, found that promise checked by "his youth and closeness to events" (122-23). Moreover, Villa's attempt to go beyond the regular story form and his met with even less approval. One reviewer condemned it outright: "There is little to say of Footnote to Youth. A boyishly thin and somewhat exotic talent is already being asked to bear more laurels than it can sustain. Mr. Villa's greatest contribution to our [italics added] short story is a typographic one: a trilogy of stories is written in short sections of a dozen lines or less, each section bearing its own serial number. This author is even more repetitive than Mr. Hemingway and Mr. Caldwell, and his simple characters repeat each sentence which they manage to achieve from one to six times" (Brande 106).

Villa's historicity was back to haunt him, its force packed in an ironically exclusionary pronoun: "our." Villa might write like an American (like Sherwood Anderson, as both the New York Times and the Saturday Review of Literature observe), but he could not be an American. He must inexorably remain a native of the Philippine Islands.

\section{From Author to Author Function}

Footnote to Youth did not sell well. When William March (William Edward Campbell) ordered two copies, Crichton replied that "the wholesale department was amazed and quite delighted to have the order on Villa's book" (12 Dec. 1933). He added, "I am afraid it has not sold too well. . . . Villa has never shown his face around since the publication of the book" (ibid.). Villa would not get another story published whether in the United States or in the Philippines.

The data on its sales in the Philippines are not forthcoming, but the book certainly caused a stir. Reading reports of Villa's activities in the United States in Philippine periodicals, one is reminded of the spin that Filipino entertainers working in Las Vegas today get from the local press. It is as though they were ever the main attraction and never the opening act. That too could be understood in the context of the colonial condition.

Since winning a short story writing contest sponsored by the Tribune in 1927 and especially after moving to the United States, Villa's stories were published in the Philippines with much paratextual matter signifying stature. For instance, his trilogy 
received some fanfare when it was published in the Graphic over a three-month period. Unlike the other stories published in the Graphic (or in other Philippine magazines), it bore a copyright note, which gave it the stamp of exclusivity, as though it were a scoop. The magazine also used boxed announcements to alert readers to when the next installment in the trilogy would be published. ${ }^{33}$ "Song I Did Not Hear," the sequel to the trilogy, also published in the Graphic, was given similar prime space and layout. "Yet Do They Strife," a Scribner's reject, was incarnated in the Philippines as "Still Is There Strife." It came with a full-page illustration in the Christmas issue of the Philippines Free Press and a note describing the story as marking "a new high level in Villa's writing" ("Something Different from Villa" 13). Villa himself was quoted: "Personally, I think it is one of the best stories I have done" (ibid.).

When Villa left the country to study in the United States, he had built quite a cachet. Regarded as a leader in the field of the short story, he had also assumed the position of literary critic, a position which surely imputed self-confidence or even arrogance. Articles about him after he had settled in the United States reinforced this image. These articles were based for the most part on what he wrote about himself in letters to friends and editors. As such, the national weekly magazines were, in effect, Villa's public relations vehicle, and being relatively isolated in the United States, he was his chief copy writer.

Villa's encounters with American writers were the stuff of reports. The Graphic announced that he was corresponding with Anderson. Anderson reportedly wrote Villa that "'The Fence' is splendid ... I liked the story 'The Son of Rizal' very, very much ... 'Malakas' did not stir me much. .. . 'Footnote to Youth' is very fine and delicately told" (qtd. in "Jose Garcia Villa among American Men of Letters" 34). The same article reported that Villa had spent an afternoon with Witter Bynner, "one of America's most famous poets" (ibid.). It quoted Villa's account of the meeting at length, including what Bynner had written on Villa's autograph album:

It was a friendly day

That brought along Jose

Brightening Santa Fe.

It also published a photograph of Villa with Bynner.

That report in the Graphic is possibly the earliest one about Villa's literary career in the United States. ${ }^{34}$ What was not reported was that it was Villa who had asked Anderson whether he, Villa, should pursue what he called the "romantic path," represented by "Malakas," or the "realistic path," represented by "Footnote to Youth," "The Man Who Looked like Rizal," and "The Fence" (3o Sept. 1931). The Graphic reported only Anderson's reply, as though it was he who had initiated the correspondence out of admiration for Villa.

The Graphic reminded readers that "both 'Malakas' and 'The Son of Rizal' were published in Graphic"; it also explained in an aside after quoting Anderson's comments that "Mr. Anderson being a realist cannot be expected to like romantic 
fantasies of which 'Malakas' is representative" ("Jose Garcia Villa among American Men of Letters" 34). From this passage, it seems that Villa's name was acquiring a "classificatory power," what Michel Foucault (107) called the 'author function." The magazine had something to gain by the association, and it was quick to establish the connection.

How "Villa" drew its power was obtained by association as well. Bynner and Anderson were already reputable American writers, and they were accepting Villa, the not-so-white sheep, as it were, to the fold. In addition, by making it seem that Anderson had volunteered to read Villa's stories, Villa (or the Graphic) created the impression that he was already becoming an important writer even in the United States. $^{36}$

Whether it was Villa who embellished the truth or the Graphic, the effect was the same: Villa obtained his halo. In hindsight, the photograph of Villa and Bynner was symbolic. The photographer, whom Villa did not identify, composed the picture so that only half of Villa's body was in the frame. Villa appears to be edging his way into the picture-and into the mainstream of American literature.

These developments were reported in the Philippines by Villa's writer friends, who quoted from his letters. Once, the Graphic even ran a boxed item entitled " . . . the latest about J. G. V." enumerating whom among the American literati he had met and where his stories or poems were going to be published (40). The reports, however, were, like the earlier account in the Graphic about Anderson and Villa, overstated, and they mentioned only such facts as removed any doubt about Villa's successes in the United States. In Federico Mangahas's column in the Tribune, one reads that Villa had "received three offers for publication of a manuscript of his under preparation - one from Alfred Knopf, publisher of Borzoi books-for American publication: one from Jonathan Cape in London, for publication in both the British Empire and the U.S.: and one from [T]his Quarter in Paris-all through the suggestion of O'Brien".$^{37}$ Litiatco in the Graphic reported that Villa had received an offer from New York and another from London to have his stories published.

It would have been more accurate to say that O'Brien recommended Villa to the editors of This Quarter and Story. Further, he merely told Villa to prepare two copies of the manuscript, which he would then offer to publishers. He was going to suggest to Knopf and Cape to "approach" Villa, and to suggest to Cape that he show a copy of "Untitled Story" to Edward Garnett (5 Apr. 1931). Of all the offers that Villa allegedly received, only one has been verified as having materialized. Story did publish "Untitled Story." This Quarter either went defunct before it could publish the story or eventually rejected it. ${ }^{38}$

Increasingly, the Philippines Free Press, like the Graphic, began to associate itself with Villa. In "Villa and the Short Story," it claimed that Villa "won recognition in the pages of the FREE PRESS," that it was the first to "recognize Villa's ability" (6). It continued: "In addition to buying several of the young writer's stories, the FREE 
PRESS published, in book form, Villa's selections of the Best Philippine Stories in 1928. Then, in 1929 it awarded Villa a prize of $\mathrm{P}_{1}, \mathrm{ooo}$ for the best short story submitted during the year" (ibid.). The following year, reporting that O'Brien was going to dedicate his annual to Villa, the magazine gave itself a pat on the back: "While the FREE PRESS does not wish to take too much credit for young Villa, it may at least feel a just pride in having been the first publication here to encourage, with payment, the art of short story writing among young Filipinos" ("Young Filipino Writer Achieves Great Honor" 50). The pitch was more subtly, though not any less disingenuously, made in 1933, upon the publication of Footnote to Youth: "FREE PRESS readers will recall 'The Fence,' 'Malakas,' 'Young Writer in a New Country,' 'Story for My Country,' and 'Yet Do They Strife,' all of which appear in the book" ("Villa's Book Is Out" 44). The article ends, "No stories of his have appeared in the Philippines since January, when the FREE PRESS published 'Still Is There Strife,' nor have any works of his published in the United States been noted locally" (ibid.). What was perhaps being insinuated was that all of the stories listed had been published in the Philippines Free Press, as though it had been Villa's magazine of choice. In fact, only three of them actually appeared in the Philippines Free Press, and Villa's opinion of its literary editor was low. ${ }^{39}$

The exact value of "Villa" was still being debated: it seems that it had come to confer some prestige at least in matters related to the short story though not in poetry. Villa's position as short story writer was strengthened by endorsements from O'Brien and Anderson, but his forays into poetry remained suspect. When his essay "The Best Poems of 1931" was published in 1932, a time when his selections of the best stories had become more or less acceptable or at least much anticipated, it was met with criticism. Readers seemed less willing to recognize him as a critic of poetry than they were ready to acknowledge or even admire him as a critic of the short story. ${ }^{40}$ When some poems of Villa's were published in the Philippines Free Press in 1932, parodies and sarcastic comments surfaced. The editors, however, kept publishing his poems - and the comments they provoked-anyway. ${ }^{41}$ Even if they were not impressed, the editors of the Philippines Free Press published Villa's odd story "She Asked Him to Come." Foreshadowing his comma poems, the story was studded with periods-between phrases, between words, and even between letters of a word ("As a Matter of Fact, We Don't Happen to Like It" 19). What the editor of a rival magazine was to declare some years later was true: however one took to Villa, he "always [made] good copy" (Litiatco, "Little Things" 78).

The charged valuation of Villa's name, like the production and consumption of Footnote to Youth, must be understood in the context of Philippine-American colonial relations. What one notices about the reports about his activities as short story writer is that they were taking on a nationalistic color. As early as 1931, the Philippines Free Press linked Villa's experiments in the short story with national honor. "The fact that Jose Garcia Villa is playing a part in that evolution [of the short story] should be a matter of pride to the Filipino people, as it is to the FREE 
PRESS" ("Villa and the Short Story" 6). A year later, in a sidebar to his story "Young Writer in a New Country," the Philippines Free Press printed an excerpt from his letter relaying the news about O'Brien dedicating the annual to him. Although the letter was a private document, the magazine editor saw it fit to make a section of it public because, he argued, "his fame reflects fame also on his people" (13). The Graphic expressed a similar sentiment, projecting Villa's personal triumph onto "all local fictionists in general" (Litiatco, "Jose Garcia Villa Goes Up Another Step" 55). Leopoldo Y. Yabes declared, "Whatever adverse opinion we have of Villa, we must be frank and honest enough to admit that he has succeeded in what our other writers have attempted but failed to do-that of putting the Philippines in the literary atlas of the world. ... It should be a source of just pride to us to have in Villa's sincere advocate of a more beautiful development of our national literature. There is no doubt but that he is exerting his best efforts for the international recognition of Filipino literature" . Finally, A. V. H. Hartendorp, the American editor of the Philippine Magazine, remarked upon the publication of Footnote to Youth, "Whatever can be said of him and his work, he is certainly the first Filipino to have received such recognition" $(1933,306)$.

"Villa," it seems, had acquired another layer of meaning in light of American colonial rule. Now that he was in the United States and there making a name for himself, he was being made to signify the colonial subject's capabilities. The publication of Villa's stories could be taken as a pitch for self-rule, especially in light of the political debates that would eventually lead to the establishment of the Commonwealth. One might even say that colonial history not only was the precondition for Villa's status as a "good copy"; it also suggested, if not determined, to what uses that status can be put.

In what is a kind of reversal of the cases analyzed in Huggan's book, Villa, the creation of Philippine media, was positioned as a proto-postcolonial champion. Still, one has to doubt just how effective or powerful this maneuver was. Villa's value was accrued from the reality of American colonization. Even the claim that Villa was an artist that the nation could be proud of can be taken as a claim in behalf of the colonizer. It assumed that it was validation from the United States that mattered; implicit was a capitulation to and an affirmation of the colonizer's standards. ${ }^{42}$ As Yu observed, Villa's "power in the Philippines relied upon his identification with the United States" ("Asian/American Modernisms" 364). Yabes's contrast between the achievement of Villa and that of his predecessors is also reflective of this bias: "True, Jose Rizal, Leona Florentino, Pedro Bukaneng, Antonio Luna, and Marcelo H. del Pilar achieved some literary recognition in Europe in their lifetime, and Marcelo de Gracia Concepcion, Ignacio Manlapaz, and Pedro de la Llana some time ago made some name for themselves in the field of American letters; but were these writers ranked with the foremost men of letters of those countries?" (63).

Once again, Villa's historicity had caught up with him. While the creation of literature may be metaphysical, the production and consumption of literature 
are material practices inevitably informed by history. It is ironic that Villa who had sought to remove history from any evaluation of his stories should be used in the service of the subject race. In another irony, Villa was being tied down to the nation-in-the-making, from which he was trying to unmoor himself.

It must be said, though, that Villa might have not been blind to the connection between nation and art himself, however much he believed art inviolate; for years later he remarked to Hartendorp-whether facetiously or not we cannot now be sure-that "Mr. Quezon should send me a round-trip ticket for the good of the nation. Let him realize that and his soul is saved" (qtd. in Hartendorp 1937, 48).

\section{Conclusion}

The publication of Villa's stories and of Footnote to Youth in the United States may indeed be a milestone in Philippine literary history, a testament of Villa's excellence as a writer. Its significance, however, is not divorced from biographical, bibliographical, and sociopolitical contexts. No matter how much Villa imagined his work as eluding history's grasp, the fingerprints of history-of PhilippineAmerican colonial relations especially-are all over the publication of his stories and the making of his book.

The Great Depression and the prevailing market taste set the conditions for his circulation in the United States. The market for short stories was small, and the market for the kind of fiction that Villa wanted to write even smaller. Villa could thus only be published in coterie magazines, whose readership consisted of people who thought as he did. Equally important, as a "native of the Philippine Islands," Villa had to play to the Orientalist tune of his American editors even as he sought to resist it. His self-ascription as a writer with universal significance was challenged and overwhelmed by the trade's (and by extension, the colonial discourse's) interpellation of him as an exotic.

While the impact of Footnote to Youth in the United States was negligible, the book was greeted with much fanfare in the Philippines, a situation reflective of the asymmetries of colonization. The imprimatur of an established American publishing house further fortified Villa's position in Philippine letters, a position that had earlier been propped up by O'Brien's legitimation of Villa.

However, as Villa's name acquired more clout because of American validation, it was also appropriated for extra-literary purposes and arguably anti-colonial ends. The rules of engagement, as it were, remained those of the colonizer, however. Villa's very triumphs in the United States and the publication of Footnote to Youth were not simply private successes but also the Filipino's at large-an ambivalent situation which both challenges and reinforces the colonial condition.

The making of Footnote to Youth, then, is all of a success story, a cautionary tale, and an allegory of a chapter of Philippine colonial history, replaying the themes of defiance and capitulation. In the story "Footnote to Youth," Dodong did not listen 
to his father because-he realizes belatedly_ "Youth must triumph ...now. Love must triumph ... now. Afterwards . . it will be Life" (Villa, Footnote 21). Villa's literary children, Filipinos who have settled abroad and who write and publish for an "international" readership, are many. What moral might they find in his story? 


\section{Notes}

1. This article benefitted from the comments, queries, and suggestions of two anonymous referees. It also owes much to the comments of Rosario Cruz-Lucero, professor at the University of the Philippines, and of John Labella, on study leave from the Ateneo de Manila University. Research assistance was provided by Leslie Morris, curator at Houghton Library, Harvard University; John Ulrich and Kuo-Kai Chin, both from the Harvard Student Agencies; and John Hickok, librarian at the California State University Fullerton. Permission to quote from the materials in the Archives of Charles Scribner's Sons was granted by the Princeton University Library. Permission to quote from the letters of Jose Garcia Villa was granted by Lance Villa, executor of the Jose Garcia Villa Estate. Access to Simeon Villa's letter was provided by John Cowen (d. 2012), lately the trustee of the Jose Garcia Villa Literary Estate.

2. Apart from Hoffman, Allen, and Ulrich, see Garvey.

3. On the "pulps," see Tim DeForest. For some circulation figures, see The Pulp Magazines Project's Web site (Belk).

4. As Hoffman, Allen, and Ulrich assert, the "glossies" were unafraid to publish these writers after the little magazine had established their reputation.

5. See Hosillos 6o-68 for an account of Anderson's influence on Villa.

6. Villa was probably emboldened by Anderson and O'Brien. Anderson praised Villa's stories (see "Jose Garcia Villa among American Men of Letters" 34), and O'Brien wrote him a letter saying that his stories "place [him] among the best writers of short stories in English" (O’Brien, Letter to Villa, 10 Jan. 1931).

7. Villa submitted at least six stories to Pagany. See the correspondence (29 May 1931, 27 Sept. 1931, 30 Oct. 1931, 17 Nov. 1931, 18 Jun. 1932, and 9 Jul. 1932) between Jose Garcia Villa and Richard Johns, editor of Pagany. I have not found any bibliographical evidence of Villa's stories' being ever published in the magazine.

8. On Villa's story's being accepted for publication in Contact, see the correspondence (12 May 1932, 20 Jul. 1932, 26 Jul. 1932) between Jose Garcia Villa and William Carlos Williams, editor of Contact. On Villa's sending a story to Contempo, see correspondence (20 Apr. 1932, 22 May 1932) between Jose Garcia Villa and Milton A. Abernethy, the editor of Contempo. Villa makes references to his being published in This Quarter in various letters, including those to Williams. A few articles published in the Philippines (e.g., Mangahas 222-223) make the same claim. When Villa's "Untitled Story" was published in the Philippines, in the Graphic, it came with this note: "Philippine rights reserved by Graphic; foreign rights by This Quarter, Paris, France." The index to This Quarter for 1931-1932, however, does not list any short story by Villa. (I am grateful to John Hickok, librarian at the Pollak Library, California State University Fullerton, who did the search.) Contact, Contempo, and This Quarter are not mentioned in the acknowledgement section of Footnote to Youth.

9. Yu writes about the racialized reception of Villa, as does E. San Juan, Jr., in "Jose Garcia Villa: Toward a Poetic Disappearance and Resistance" and "Jose Garcia 
Villa-Critique of a Subaltern Poetics." Both authors must be cited for having developed this thesis.

10. Crichton's letter refers to the story as one that Villa had sent "when you [Villa] were still in Manila." The letters between Crichton and Villa are in the Scribner's Archives, Firestone Library, Princeton University.

11. In the story "Yet Do They Strife," a child running away from an abusive father finds a "Man" lying in a bed of flowers. The boy helps the tired man up, and they walk to a brook for the Man to drink. The child feels an inexplicable sense of love and wishes that the Man were his father. The Man urges the child to return home but the Man says that he himself cannot go home yet because "The Earth needs me." The child returns home "thinking of when they would meet again." As published in a Christmas issue of the Philippines Free Press the story came with an illustration that identified the Man as Jesus Christ.

12. The letter is undated but Villa's reply is dated 7 September 1930: "I want to thank you for the wonderful letter you sent me. It was truly good of you to write it, and I think your advice is right. I will not try to be an American."

13. Yu ("Asian/American Modernisms" 346-347) reads a similar anxiety into a review of the book in the New York Times.

14. Huggan notes that writers like Salman Rushdie and Arundhati Roy know how to "manipulate commercially viable metropolitan codes" and turn that ability against their metropolitan readers, but they also know that their "ostensibly oppositional" work is "vulnerable to recuperation," available to be "used as a means of reconfirming an exoticising imperial gaze" (81). It would be interesting to juxtapose Huggan with Fernando Nakpil Zialcita's hypothesis in Authentic though not Exotic that the culture of lowland Filipino Christians (to which group Villa belonged) is not "exotic" enough-because not "authentic"-for it to be adequately represented in American exhibitions of Asia.

15. The story was published in Story 1 (Nov-Dec 1931): 45-53.

16. See Cruz's study and also Garcia's article in the Philippines Free Press.

17. The quotation comes from the text as published in the Prairie Schooner. There are variants in the substantives between the text in Prairie Schooner and that in Footnote to Youth.

18. The theme is common to all the "Rizal stories" of Villa. See Holden's analysis in Life Writing.

19. The following chapter in the history of Scribner's is apropos: in 1898, a story by South African writer William Charles Scully was accepted by Scribner's. The endorsement came from Rudyard Kipling. Writing out of a sense of "high moral duty," Kipling had suggested that the story be published because "now that your land [the United States] is going to have subject races of her own, she must take an interest in the thoughts and fancies of such folks" (qtd. in Burlingame 48-49). It would not be completely vain, then, to suppose that a similar process was at work in Villa's case, thirty-odd years later it may have been; for Scribner's apparently had not been above Orientalist fascination. 
20.Yu, among other scholars, notes that a strain in modernism fetishizes and appropriates "native" productions but also excludes "native" subjects as practitioners of the modernist aesthetic.

21. On Villa's attitude toward formal schooling, see Marquardt 48.

22. Villa had offered it to Pagany (Villa, Letter to Richard Johns, 9 Jul. 1932).

23. Compared to other writers, Hemingway was not quite a bestselling author in the 30 , although he was reputable enough to be worth the investment, his commercial value increasing in the 1940s (Hart 270). For the number of copies of Hemingway's books in libraries in 1933, the year that Footnote to Youth was published, see Hart 234. See also Marketing Modernism between the Two World Wars by Catherine Turner for a study of how Scribner's advertisements of Hemingway's book helped readers overcome their anxieties about the perceived difficulties of reading a modernist writer.

24. According to the Philippines Free Press, Villa used the money that his father had sent for him to pay for the fare for his trip back to the Philippines ("Book of Villa's Stories" 48).

25. The density of these words is high in the first two stories in the collection: "Footnote to Youth" and "The Fence." Whether or not these words serve as "metonymic gaps" (Ashcroft, Griffiths, and Tiffin 137-138) or a kind of protest to colonial hegemony is a question for further study.

26. The two-page document is unsigned and simply has "Footnote to Youth Tales of the Philippines and Others by Jose Garcia Villa" as its header. In two places there are handwritten alterations.

27. See Quijano de Manila [Nick Joaquin] 185-193; see also Abad and Manlapaz 411412, and Espiritu 76.

28."Untitled Story," if taken as straightforward biography, would lend some support to San Juan's hypothesis. Joaquin takes the conflict between father and son as a clash of cultures, the dying Hispanic culture and the emerging Saxon culture, an interpretation that is not irreconcilable with San Juan's (see Quijano de Manila 185-187).

29. The stories were prize-winners in the Philippines. "Mirla" won Villa his first first prize at a national short story writing contest; "Mir-i-nisa" his last, and one whose prize money, he said, afforded him the ticket to a seat in a liner to the United States (Alegre and Fernandez 299-300).

3o. San Juan, Jr., points out that Villa's universalist aesthetics "[fit] perfectly the imperialist strategy of deflecting the people's revolt against physical suffering, disease, and untold privations experienced by the peasantry and the proletariat" (Toward 75). But see Cruz's article, which interprets Villa's stories as challenging the myth of American liberalism.

31. Hosillos deserves credit for being the first to survey the reviews that the book received and for employing a postcolonial approach even before postcolonial theory became widespread in academe. It must be pointed out, though, that her survey might not have been comprehensive.

32. A caveat: we do not know how many reviews there were of the book. 
33. The stories were published, in order, in the following issues: 9 Sept. 1931, 28-30; 7 Oct. 1931, 24-25, 30, 40; and 4 Nov. 1931, 25-26, 30.

34. The Philippines Free Press had published "A University Student's Letter" on 20 Sept. 1930, but that was Villa's personal letter to a staff member of the Free Press. It contained no reference to his short story pursuits; rather, it was a record by a wide-eyed Manileño's first encounter with America. Villa is enchanted by Hollywood-he was able to tour the RKO studio-and "can hardly wait to see real good snow-we don't have snow in the Philippines!" (14).

35. See Foucault 101-120.

36. Anderson's penmanship is difficult to decipher. What he seems to have written is this: "It seems to me the story The Fence really [sad?] where I have marked it. It is splendid if you [illegible] all the rest" (Anderson, Letter 1 to Villa, n.d.). In the letter, Anderson did pay compliments to Villa.

37. The column was originally published in the Tribune, 27 May 1931. This article uses the reprint of the column in Mangahas's collection Maybe: Incidentally, edited by Ruby K. Mangahas.

38. See note 8.

39. See Alegre and Fernandez 298 and Critical Villa 239-241, 282.

40. See "Brickbats for Mr. Villa," which consisted of articles pro and con on Villa's selection of the best Filipino poems of 1931.

41. Such, for instance, was de la Costa and Guerrero 52.

42. Cf. the "staged marginalities" of Hanef Kureishi in Huggan 94-104. The present case may be likened to a staged protest that nobody attends.

\section{Works Cited}

Abad, Gemino H. and Edna Z. Manlapaz. Man of Earth: An Anthology of Filipino Poetry and Verse from English 1905 to the Mid-5os. Quezon City: Ateneo de Manila UP, 1989. Print.

Alegre, Edilberto N. and Doreen G. Fernandez. The Writer and His Milieu. Manila: De La Salle UP, 1984. Print.

Anderson, Sherwood. Letter 1 to Jose Garcia Villa. n.d. Houghton Library.

--. Letter 2 to Jose Garcia Villa. n.d. Houghton Library.

“As a Matter of Fact, We Don't Happen to Like It." Philippines Free Press 6 May 1933: 19. Print.

Ashcroft, Bill, Gareth Griffiths, and Helen Tiffin. Post-Colonial Studies: The Key Concepts. London: Routledge, 200o. Print.

Bates, Jonathan, gen. ed. General Introduction. Oxford English Literary History. Oxford: Oxford UP, 2002. Print.

Belk, Patrick. The Pulp Magazines Project. U of West Florida, Jul. 2011. Web. 25 Jun. 2013.

"Book of Villa's Stories Being Published." Philippines Free Press 22 Jul. 1933: 48. Print. 
Brande, Dorothea. "Mr. Ford and American Fiction." American Review 2.1 (1933): 101107. Print.

"Brickbats for Mr. Villa." Philippines Free Press 16 Jan. 1932: 10, 50-51. Print.

Brunschwig, Andre. "What I Think of Our Short Story Writers." Philippines Herald 3 Mar. 1929: 5. Print.

Burlingame, Roger. Of Making Many Books. New York: Scribner's, 1946. Print.

Burt, Daniel S., ed. The Chronology of American Literature. Boston: Houghton-Mifflin, 2004. Print.

Crichton, Kyle S. Letter to Harvey Fergusson. 14 Sept. 1931. Scribner's Archives. Firestone Library, Princeton U.

--. Letter to William March. 12 Dec. 1933. Scribner's Archives. Firestone Library, Princeton U.

--. Letter to Jose Garcia Villa. 19 Mar. 1931. Scribner's Archives. Firestone Library, Princeton U.

--. Letter to Jose Garcia Villa. 14 Apr. 1931.

--. Letter to Jose Garcia Villa. 3 Aug. 1931.

--. Letter to Jose Garcia Villa. 24 Oct. 1931.

--. Letter to Jose Garcia Villa. 22 Mar. 1932.

--. Letter to Jose Garcia Villa. 8 Apr. 1932.

--. Letter to Jose Garcia Villa. 6 Jun. 1932.

--. Letter to Jose Garcia Villa. 4 Nov. 1932.

--. Letter to Jose Garcia Villa. 18 May 1933.

--. "Advice to a Young Man about to Lose His Shirt." Clay 1 (1931): i-iv. Print.

Cruz, Denise. "Jose Garcia Villa's Collection of 'Others': Irreconcilabilities of a Queer Transpacific Modernism." Modern Fiction Studies 55 (2009): 11-41. Print.

De la Torre Bueno, Jr., J.R. Letter to Jose Garcia Villa. 7 Apr. 1932. Granville Hicks Papers. Syracuse U Library, Syracuse U.

--. Letter to Granville Hicks. 21 Apr. 1932. Granville Hicks Papers. Syracuse U Library, Syracuse U.

De la Costa, Horacio and Leon Ma. Guerrero. "Another Crack at Villa's Verse." Philippines Free Press 29 Oct. 1932: 52. Print.

De Manila, Quijano [Nick Joaquin]. Doveglion and Other Cameos. Manila: National Book Store, 1977. Print.

DeForest, Tim. Storytelling in the Pulps, Comics, and Radio: How Technology Changed Popular Fiction in America. Jefferson: McFarland, 2004. Print.

Espiritu, Augusto Fauni. Five Faces of Exile: The Nation and Filipino American Intellectuals. Stanford: Stanford UP, 2005. Print.

Fergusson, Harvey. Letter to Kyle S. Crichton. 9 Sept. 1931. Scribner's Archives. Firestone Library, Princeton U.

"Footnote to Youth Tales of the Philippines and Others by Jose Garcia Villa." N.d. TS. Promotional Material. Scribner's Archives. Firestone Library, Princeton U.

Foucault, Michel. "What Is an Author?" Power/Knowledge: Selected Interviews and Other Writings 1972-1977. Ed. Colin Gordon. New York: Pantheon, 1980. 101-120. Print. Garcia, J. Neil. "Villa (Re)discovered." Philippines Free Press 2 Aug. 1997: 39. Print. 
Garvey, Ellen Gruber. "Out of the Mainstream and into the Streets: Small Press Magazines, the Underground Press, Zines and Artists' Books." Perspectives on American Book History. Ed. Scot E. Casper, Joanne D. Chaison, and Jeffrey D. Groves. Amherst: U of Massachusetts P, 2002. 368, 390-393. Print.

Hart, James D. The Popular Book: A History of America's Literary Taste. New York: Oxford UP, 1950. Print.

Hartendorp, A.V.H. “Four O'Clock in the Editor's Office." Philippine Magazine Oct. 1932: 226-228. Print.

--. "Four O'Clock in the Editor's Office." Philippine Magazine Dec. 1933: 306-307. Print.

--.. "Four O'Clock in the Editor's Office." Philippine Magazine Jan. 1937: 47-51. Print.

Hoffman, Frederick J., Charles Allen, and Carolyn F. Ulrich. The Little Magazine: A History and a Bibliography. Princeton: Princeton UP, 1946. Print.

Holden, Philip. "Unbecoming Rizal: Jose Garcia Villa's Biographical Translations." Life Writing (Dec. 2009): 287-302. Print.

Hosillos, Lucila V. Philippine-American Literary Relations. Quezon City: U of the Philippines P, 1968. Print.

Huggan, Graham. The Post-Colonial Exotic: Marketing the Margins. London: Routledge, 2001. Print.

"Jose Garcia Villa among American Men of Letters." Graphic 29 Oct. 1930: 34. Print.

Korda, Michael. Making the List: A Cultural History of the American Bestseller 1900-1999. New York: Barnes and Noble, 2001. Print.

“. . the latest about J.G.V." Graphic 23 Dec. 1931: 40. Print.

Litiatco, A.E. "Jose Garcia Villa Goes Up Another Step." Graphic 30 Sept. 1931: 6, 37, 55. Print.

--.. "Jose Garcia Villa's First Book: 'Footnote to Youth"' Graphic 2 Nov. 1933: 20, 47. Print.

--- "Little Things." Graphic 7 Jan. 1937: 78. Print.

--.. "The Why of Rejection Slips." Graphic 8 Feb. 1934: 12-13, 45, 48. Print.

Mangahas, Federico. "Fat People." Maybe: Incidentally. The Satire of Federico Mangahas. Ed. Ruby K. Mangahas. Quezon City: U of the Philippines P, 1998. 222-223. Print.

Marquardt, Frederic S. "Not Interested in Diplomas." Philippines Free Press 6 Aug. 1932: 48-49, 62. Print.

McElvaine, Robert S. The Great Depression: America, 1929-1941. New York: Times, 1993. Print.

O’Brien, Edward J. ed. Best Short Stories of 1932. New York: Dodd, 1932. Print.

--.. "Introduction." Footnote to Youth: Tales of the Philippines and Others. Jose Garcia Villa. New York: Scribner's, 1933. 3-5. Print.

--. Letter to Jose Garcia Villa. 10 Jan. 1931. Jose Garcia Villa Papers. Houghton Library, Harvard U.

--. Letter to Jose Garcia Villa. 5 Apr. 1931.

--. Letter to Jose Garcia Villa. 18 Jul. 1931.

Perkins, Maxwell. Letter to Jose Garcia Villa. 31 Jul. 1932. Scribner's Archives. Firestone Library, Princeton U.

-.-. Letter to Jose Garcia Villa. 1 Jun. 1933.

--. Letter to Jose Garcia Villa. 5 Jun. 1933. 
Petersen, Theodore. Magazines in the Twentieth Century. Urbana: U of Illinois P, 1956. Print.

Ponce, Martin Joseph. "Jose Garcia Villa's Modernism and the Politics of Queer Diasporic Reading." GLQ: A Journal of Lesbian and Gay Studies 17 (2011): 575-602. Print.

Quirino, Carlos. “Insurgent Villa: Modernist, Idealist." Graphic 26 Oct. 1932: 8-9, 49, 61, 63. Print.

Sabado, Domingo. "How They Write Their Short Stories: An Interview with Leading Local Short Story Writers, ii. Jose Garcia Villa." Graphic 16 Feb. 1929: 50. Print.

San Juan, E., Jr., "Jose Garcia Villa-Critique of a Subaltern Poetics." EurAmerica 4O (2010): 1-29. Print. Earlier published as "Jose Garcia Villa: Vicissitudes of Neocolonial Art-Fetishism and the 'Beautiful Soul' of the Filipino People." Kritika Kultura 13 (2009): 5-22. Web. 25 Jun. 2013.

--. "Jose Garcia Villa-Toward a Poetics of Disappearance and Resistance." Reading the West/Writing the East. New York: Peter Lang, 1992. 95-132. Print. This essay was also published in History and Form: Selected Essays (Quezon City: Ateneo de Manila UP, 1996) and in The Philippine Temptation: Dialectics of Philippine-U.S. Literary Relations (Philadelphia: Temple UP, 1996).

--. Toward a People's Literature: Essays in the Dialectics of Praxis and Contradiction in Philippine Writing. Quezon City: U of the Philippines P, 1984. Print.

"A Short Story from Villa." Philippines Free Press 9 Jul. 1932: 12. Print.

"Something Different from Villa." Philippines Free Press 31 Dec. 1932: 13. Print.

Turner, Catherine. Marketing Modernism between the Two World Wars. Amherst: U of Massachusetts P, 2003. Print.

"Villa and the Short Story." Philippines Free Press 3 Oct. 1931: 6. Print.

"Villa Protests." Philippines Free Press 30 Aug. 1958: 139. Print.

Villa, Jose Garcia. The Critical Villa: Essays in Literary Criticism by Jose Garcia Villa. Ed. Jonathan Chua. Quezon City: Ateneo de Manila UP, 2002. Print.

--. Footnote to Youth: Tales of the Philippines and Others. New York: Scribner's, 1933. Print.

--. "Given Woman." Graphic 23 Dec. 1931: 22, 51. Print.

--. Letter to Milton A. Abernethy. 20 Apr. 1932. Contempo Collection. Harry Ransom Center, $\mathrm{U}$ of Texas at Austin.

--- Letter to Milton A. Abernethy. 22 May 1932.

--. Letter to Sherwood Anderson. 7 Feb. 1930. Sherwood Anderson Papers. Newberry Library.

--. Letter to Sherwood Anderson. 7 Sept. 1930.

--. Letter to Kyle S. Crichton. 7 Mar. 1931. Scribner's Archives. Firestone Library, Princeton U.

--. Letter to Kyle S. Crichton. 23 Mar. 1931.

--. Letter to Kyle S. Crichton. 11 Jul. 1932.

--. Letter to Kyle S. Crichton. 17 May1933.

--. Letter to Kyle S. Crichton. 23 May 1933.

--. Letter to Richard Johns. 29 May 1931. Pagany Archive. U of Delaware Library.

--. Letter to Richard Johns. 27 Sept. 1931.

--. Letter to Richard Johns. 30 Oct. 1931. 
---. Letter to Richard Johns. 17 Nov. 1931.

--.. Letter to Richard Johns. 18 Jun. 1932.

--. Letter to Richard Johns. 9 Jul. 1932.

--. Letter to Maxwell Perkins. 26 May 1933. Scribner's Archives. Firestone Library, Princeton U.

--. Letter to Maxwell Perkins. 14 Jun. 1933.

--. Letter to William Carlos Williams. 5 Aug. 1931. William Carlos Williams Papers. Beinecke Rare Books and Manuscript Library, Yale U.

--.. Letter to William Carlos Williams. 12 May 1932.

--. Letter to William Carlos Williams. 20 Jul. 1932.

--.. "Malakas: A Story of Old-Time Philippines." New Mexico Quarterly 1 (May 1931): 167176. Print.

--. "The Son of Rizal." Prairie Schooner 6.1 (Winter 1932): 1-9. Print.

--. "A University Student's Letter." Philippines Free Press 20 Sept. 1930: 14-15. Print.

--. "Untitled Story." Story 1 (Nov.-Dec. 1931): 45-53. Print.

--.. "Untitled Story." Graphic 9 Sept. 1931: 28-30. Print.

--.. "Walk at Midnight." Graphic 4 Nov. 1931: 25-26, 30. Print.

--.. "White Interlude." Graphic 7 Oct. 1931: 24-25, 30, 40. Print.

--. "Young Writer in a New Country." Philippines Free Press 9 Jul. 1932: 12-13. Print.

Villa, Simeon. Letter to Jose Garcia Villa. 5 Sept. 1932. Personal Library of John Cowen.

"Villa's Book Is Out." Philippines Free Press 28 Oct. 1933: 44.

Williams, William Carlos. Letter to Jose Garcia Villa. 26 Jul. 1932. William Carlos Williams Papers. Beinecke Rare Books and Manuscript Library, Yale U.

Wright, Austin McGiffert. The American Short Story in the Twenties. Chicago: Chicago UP, 1961. Print.

Yabes, Leopoldo. "Sizing Up Villa." Graphic 25 May 1933: 6-62, 63. Print.

"Young Filipino Writer Achieves Great Honor." Philippines Free Press 4 Jun. 1932: 50. Print.

Yu, Timothy. "Asian/American Modernisms: Jose Garcia Villa's Transnational Poetic." Pinoy Poetics: A Collection of Autobiographical and Critical Essays on Filipino and Filipino American Poetics. Ed. Nick Carbo. San Francisco: Meritage, 2004. 343-367. Print.

--. “'The Hand of a Chinese Master': Jose Garcia Villa and Modernist Orientalism." MELUS 29 (2004): 41-59. Print.

Zialcita, Fernando Nakpil. Authentic though Not Exotic: Essays on Filipino Identity. Quezon City: Ateneo de Manila UP, 2005. Print. 